\title{
PERTANGGUNGJAWABAN KHPM DALAM PROSES IPO JIKA TERDAPAT FAKTA MATERIAL YANG TIDAK DIUNGKAP ${ }^{1}$
}

\author{
Hendrawan Agusta \\ Program Studi Magister Ilmu Hukum, Fakultas Hukum, Universitas Indonesia \\ Jalan Salemba Raya No. 4, Jakarta \\ hagusta@yahoo.com
}

\begin{abstract}
Initial Public Offering (IPO) is an activity to offer and sell securities to public for the first time as one of the way for a company to obtain capital injection. IPO involving Capital Market Legal Consultant (CMLC) who has important role and influence to Investors' decision. CMLC make legal audit and legal opinion which will be merged in Prospectus by applying Disclosure. Problem arising out if CMLC fail to deliver accurate Material Fact in its legal opinion. By normative research method, this journal will elaborate the responsibility of CMLC if there is an undisclosed Material Fact in Prospectus, relevant authority which competent to state that CMLC is violate regulation, as well as whether the regulation and Professional Standard of CMLC has properly regulated indemnity procedures to Investor when such CMLC fails to deliver accurate Material Fact in IPO.
\end{abstract}

Keywords: IPO; Capital Market Legal Consultant; Disclosure; Material Fact

\begin{abstract}
Abstrak
Initial Public Offering (IPO) adalah kegiatan penawaran dan penjualan saham perdana kepada masyarakat sebagai salah satu cara bagi perusahaan untuk mendapatkan tambahan modal. Proses IPO melibatkan Konsultan Hukum Pasar Modal (KHPM) yang mempunyai peranan penting dan berpengaruh terhadap keputusan Investor. KHPM melakukan pemeriksaan dokumen hukum dan membuat pendapat hukum yang tercantum dalam Prospektus dengan menerapkan Prinsip Keterbukaan. Muncul masalah jika KHPM tidak mengungkap Fakta Material dalam pendapat hukumnya. Dengan metode penelitian normatif, jurnal ini akan membahas pertanggungjawaban KHPM dalam hal terdapat Fakta Material yang tidak diungkap dalam Prospektus, lembaga mana yang berwenang untuk menyatakan KHPM telah melanggar peraturan hukum, dan apakah peraturan hukum yang ada dan Standar Profesi KHPM telah cukup mengatur proses pemberian ganti rugi kepada Investor dalam hal KHPM tidak mengungkap Fakta Material dalam IPO.
\end{abstract}

Kata Kunci: IPO; Konsultan Hukum Pasar Modal; Prinsip Keterbukaan; Fakta Material

\footnotetext{
${ }^{1}$ Artikel Hasil Penelitian.
} 


\section{A. Pendahuluan}

Suatu perusahaan yang melakukan IPO akan memperoleh keuntungan, antara lain mendapatkan tambahan modal daripada harus melalui kredit pembiayaan (debt financing) dan dapat melakukan penawaran efek di pasar sekunder (Nasarudin \& Surya, 2004). Peraturan Otoritas Jasa Keuangan Nomor 7/POJK.04/2017 tentang Dokumen Pernyataan Pendaftaran dalam Rangka Penawaran Umum Efek Bersifat Ekuitas, Efek Bersifat Utang, Dan/Atau Sukuk (POJK No. 7/2017) mengatur bahwa sebelum melakukan IPO, sebuah perusahaan wajib membuat dokumen Pernyataan Pendaftaran yang terdiri dari Surat Pengantar Pernyataan Pendaftaran, Prospektus, Prospektus Ringkas, Propsektus Awal (jika ada) serta dokumen lainnya yang harus disampaikan. Peraturan Otoritas Jasa Keuangan Nomor 8/POJK.04/2017 tentang Bentuk dan Isi Prospektus dan Prospektus Ringkas dalam Rangka Penawaran Umum Efek Bersifat Ekuitas (POJK No. 8/2017) mengatur bahwa Prospektus adalah setiap informasi tertulis sehubungan dengan penawaran umum dengan tujuan agar pihak lain membeli Efek.

KHPM melakukan uji tuntas atas berbagai aspek hukum (Legal Due Diligence) terhadap Emiten maupun entitas anak perusahaan Emiten sesuai aturan hukum dan Standar Profesi Himpunan Konsultan Hukum Pasar Modal (HKHPM). Due Diligence dapat dimaknakan sebagai suatu penelitian yang mendalam, yang dilakukan oleh Konsultan hukum pasar modal dalam proses penawaran umum oleh Emiten (Rohendi, 2017). Hasil uji tuntas tersebut kemudian dituangkan ke dalam Pendapat Hukum sebagai bagian dari Prospektus. Pendapat hukum ini menjadi salah satu acuan bagi Investor di pasar modal untuk menentukan keputusannya berinvestasi. Pasar modal memiliki fungsi sebagai sarana pembiayaan yang mempertemukan investor sebagai pihak yang memiliki dana lebih dengan Emiten yakni pihak yang sedang memerlukan dana (Sujatmiko \& Suryanti, 2017).
Berdasarkan Undang-Undang Nomor 8 Tahun 1995 tentang Pasar Modal (UU No. 8 Tahun 1995), KHPM wajib menerapkan Prinsip Keterbukaan (Disclosure), yaitu pedoman umum untuk menginformasikan masyarakat dalam waktu yang tepat seluruh informasi material mengenai usahanya atau efeknya yang dapat berpengaruh terhadap keputusan pemodal terhadap Efek dimaksud dan/atau harga dari Efek yang dimaksud. Prinsip Keterbukaan juga didefenisikan sebagai pengungkapan data perusahaan secara lengkap dan menyeluruh menyangkut data keuangan, pengurus dan sebagainya dengan tujuan agar diketahui secara luas oleh masyarakat umum (Haidar, 2015).

Pemeriksaan hukum oleh KHPM mengungkapkan secara jelas dan terbuka (Disclosure) dokumen-dokumen yang diperiksa dalam rangka penawaran hokum (Purba, 1995). Prinsip ini bertujuan untuk melindungi masyarakat pembeli saham atau investor (Balfas, 1994). Fakta Material adalah informasi atau fakta penting dan relevan mengenai peristiwa, kejadian, atau fakta yang dapat mempengaruhi harga Efek pada Bursa Efek dan atau keputusan pemodal, calon pemodal, atau pihak lain yang berkepentingan atas informasi atau fakta tersebut. Fakta Material tersebut harus diungkap secara terbuka kepada investor. Teori mengenai Prinsip Keterbukaan di bidang pasar modal (Disclosure) inilah yang menjadi pisau analisa dalam penelitian ini.

Mengenai Prinsip Keterbukaan di pasar modal kaitannya dengan tanggung jawab KHPM, telah ada beberapa penelitian berupa jurnal ilmiah yang membahasnya. Pada umumnya membahas tanggung jawab KHPM dalam proses IPO yang wajib melaksanakan Prinsip Keterbukaan. Dalam penelitian sebelumnya, para penulis lebih berfokus kepada akibat hukum apabila Prinsip Keterbukaan tersebut dilanggar oleh KHPM, mulai dari sanksi administratif sampai risiko adanya gugatan perdata terhadap KHPM. Namun penelitian tersebut belum ada yang membahas dan menganalisa lembaga mana yang berwenang untuk menentukan ada atau tidaknya pelanggaran 
Prinsip Keterbukaan oleh KHPM jika ditemukan Fakta Material yang tidak diungkap.

Dalam penelitian ini, penulis menambahkan hal baru berupa contoh kasus kewenangan mengadili sengketa pasar modal antara Investor dan Emiten yang belum pernah dibahas oleh penelitian sebelumnya. Contoh kasus tersebut penulis jadikan sebagai pengantar untuk kemudian dianalisa menggunakan pendekatan perundang-undangan.

Dalam sejarah pasar modal di Indonesia tercatat pernah ada Gugatan Perbuatan Melawan Hukum dan Ganti Rugi yang diajukan Abdul Malik Jan (Penggugat) yang salah satunya ditujukan kepada KHPM, sebagaimana Perkara No. 29/PDT.G/2011/PN.JKT.PST. pada Pengadilan Negeri Jakarta Pusat. Gugatan ini diajukan oleh Penggugat selaku pemilik 32.500 lembar saham PT. Media Nusantara Citra, Tbk (MNC) sehubungan dengan IPO MNC di bulan Juni 2007. Pokok perkara Gugatan adalah Penggugat menemukan fakta pada bulan Juni 2010 hingga bulan Desember 2010 terdapat berita sengketa kepemilikan saham pada PT Cipta Televisi Pendidikan Indonesia (TPI) antara MNC dan Siti Hardiyanti Rukmana. Somasi kepada MNC dari Siti Hardiyanti Rukmana telah berkali-kali dilayangkan sejak tahun 2005 . Namun, hal tersebut tidak diungkap dalam Prospektus. Selain itu, dalam Prospektus dicantumkan TPI adalah anak perusahaan sah MNC dan berkontribusi cukup signifikan atas pendapatan MNC sebesar 21.9\%. Padahal, apabila sengketa kepemilikan saham TPI tersebut dicantumkan dalam Prospektus MNC, harga saham IPO MNC belum tentu mencapai angka Rp 900,- (sembilan ratus rupiah) per lembar saham. Penggugat yang sudah terlanjur membeli saham MNC merasa hak keperdataanya dirugikan, sehingga menuntut ganti rugi, salah satunya kepada KHPM dengan dasar Pasal 80 ayat (1) dan ayat (2) jo. Pasal 80 ayat (4) UU No. 8 Tahun 1995. Namun, Pengadilan Negeri Jakarta Pusat menyatakan tidak dapat menerima gugatan tersebut, dengan pertimbangan bahwa ada atau tidaknya pelanggaran di bidang pasar modal harus diperiksa dahulu melalui Bapepam-LK (saat Putusan dikeluarkan, belum dibentuk OJK).

Berdasarkan uraian latar belakang tersebut, berikut ini adalah rumusan permasalahan yang akan dibahas dalam Jurnal ini : (1) Bagaimana bentuk pertanggungjawaban KHPM yang melakukan kesalahan dalam melakukan uji tuntas segi hukum dalam rangka IPO?; (2) Pihak mana yang berwenang menyatakan bahwa KHPM melakukan kesalahan atau pelanggaran dalam uji tuntas segi hukum dalam rangka IPO?; (3) Apakah peraturan perundang-undangan maupun Standar Profesi HKHPM yang ada saat ini telah cukup mengatur mengenai pertanggungjawaban KHPM khususnya dalam bentuk ganti kerugian terkait kesalahan yang dilakukannya?

\section{B. Metode Penelitian}

Metode penelitian yang digunakan dalam penelitian ini adalah penelitian hukum normatif atau penelitian hukum doktrinal, yaitu penelitian perpustakaan atau studi dokumen karena penelitian ini dilakukan atau ditujukan hanya pada peraturan-peraturan yang tertulis atau bahanbahan hukum yang lain (Soekanto \& Mamudji, 2004). Penelitian doktrinal terdiri dari penelitian yang berupa usaha inventarisasi hukum positif, penemuan asasasas dan falsafah (dogma atau doktrin) hukum positif, dan penemuan hukum in concreto yang layak diterapkan untuk menyelesaikan suatu perkara hukum tertentu (Wiradipradja, 2016). Penelitian ini bersifat deskriptif, dimaksudkan untuk memberikan data yang seteliti mungkin tentang manusia, keadaan atau gejala-gejala lainnya, maksudnya terutama untuk mempertegas hipotesa-hipotesa, agar dapat membantu di dalam memperkuat teori-teori lama (Soekanto, 2015). Dalam penelitian ini yang akan dielaborasi adalah Teori mengenai Prinsip Keterbukaan (Disclosure) di bidang pasar modal. 
Jenis dan data yang digunakan dalam penelitian ini adalah bahan hukum primer dan bahan hukum sekunder. Bahan hukum primer merupakan bahan hukum yang bersifat autoritatif, artinya mempunyai otoritas (Marzuki, 2014). Bahan-bahan hukum primer terdiri dari perundangundangan, catatan-catatan resmi atau risalah dalam pembuatan perundang-undangan dan putusan-putusan hukum (Marzuki, 2014). Adapun bahan-bahan sekunder berupa semua publikasi tentang hukum yang bukan merupakan dokumen-dokumen resmi, berupa publikasi tentang hukum, meliputi buku-buku teks, kamus-kamus hukum, jurnal-jurnal hukum dan komentar-komentar atas putusan pengadilan. Setelah penulis mengumpulkan sumber bahan hukum, dalam penelitian ini penulis menggunakan pendekatan undang-undang (statute approach), yaitu dilakukan dengan menelaah semua undang-undang dan regulasi yang bersangkut paut dengan isu hukum yang sedang ditangani (Marzuki, 2014). Meskipun dalam Pendahuluan penulis mencantumkan perkara di pengadilan, namun penulis tidak menggunakan pendekatan kasus (case approach) oleh karena hal tersebut hanya sebagai pengantar agar Jurnal ini lebih mudah dipahami pembahasannya. Penelitian ini adalah penelitian hukum normatif, sehingga metodenya analisa datanya bersifat kualitatif, tidak berbentuk angka (Wiradipradja, 2016).

\section{Hasil Penelitian dan Pembahasan}

\section{Pertanggungjawaban KHPM dalam melakukan Uji Tuntas Pada IPO}

Peran KHPM bagi Emiten dalam IPO diperlukan untuk memeriksa dokumen hukum (Legal Audit) dan memberikan pendapat dari segi hukum (Legal Opinion) mengenai keadaan Emiten melalui proses uji tuntas (Sutedi, 2009). Legal Opinion adalah dokumen yang dipersiapkan oleh seorang konsultan hukum untuk kliennya, yang berisi pemahamannya dari sudut hukum yang berlaku terhadap suatu fakta yang disampaikan kepadanya untuk itu (Purba, 1990). Berdasarkan Peraturan OJK Nomor 66/POJK.04/2017 tentang Konsultan Hukum Yang Melakukan Kegiatan Di Pasar Modal, KHPM harus terdaftar di Otoritas Jasa Keuangan (OJK) sebagai ahli hukum yang dapat memberikan pendapat hukum kepada pihak lain yang melakukan kegiatan dibidang pasar modal. Perusahaan Publik atau Emiten yang ingin sahamnya dibeli oleh para investor dan dapat masuk dalam standard internasional, haruslah berusaha untuk membuka diri dan menerapkan Keterbukaan Informasi dengan kualitas yang terjaga dalam hal akurasi, kelengkapan, ketepatan waktu dan ketepatan informasi (Ratna, 2006). KHPM dapat mengalami tantangan dalam menjalankan kewajiban uji tuntas untuk membuat pendapat hukum mengenai keadaan Emiten apabila terjadi pertentangan dalam penerapan Prinsip Keterbukaan dari Emiten kepada Investor sebagai berikut: (a) Investor menginginkan keterbukaan informasi secara menyeluruh mengenai Emiten, sedangkan Emiten hanya bersedia membuka informasi hingga tingkatan tertentu; (b) Investor menginginkan informasi yang update, sementara Emiten berusaha menahan informasi tertentu untuk beberapa waktu dengan alasan pengurangan biaya penerbitan laporan; (c) Investor menginginkan memperoleh data yang rinci dan akurat, sementara Emiten hanya bersedia memberikan informasi secara garis besar. (Nasarudin \& Surya, 2004)

Meskipun terdapat tantangan, KHPM wajib menerapkan Prinsip Keterbukaan terhadap kepatuhan Emiten yang menjadi klien mereka untuk selalu membuka Fakta Material. Legal Audit dipakai oleh seorang KHPM sebagai landasan untuk membuat Legal Opinion, serta Legal Opinion ini akan dimuat dalam Prospektus Emiten karena informasi dalam Prospektus seharusnya memberikan pengetahuan yang cukup dan dapat digunakan sebagai bahan pertimbangan dalam membuat keputusan untuk membeli saham dan bermanfaat sebagai salah satu cara melindungi Investor 
dari penjualan yang curang atau fraudulent sales (Nasution, 2011). Keterbukaan ini penting sehingga masyarakat memperoleh gambaran yang lengkap dan tepat tentang perusahaan sebelum mengambil keputusan untuk ikut menanamkan uangnya (Nasarudin, 2017). Berdasarkan Standar Profesi Himpunan Konsultan Hukum Pasar Modal (Lampiran Keputusan HKHPM No. Kep. 01/HKHPM/2005), KHPM melakukan uji tuntas dengan cara: (a) Pemeriksaan atas dokumen dilakukan dengan meneliti dan menganalisa semua dokumen yang dianggap perlu dan material sehubungan dengan transaksi yang akan dilakukan; (b) Pemeriksaan yang dilakukan melalui tanya jawab yang dapat dilakukan dengan cara wawancara dengan pihak manajemen dan pihak yang ditunjuk oleh manajemen, serta pihak terkait lainnya yang berhubungan dengan obyek transaksi; (c) Turut serta dalam pertemuan uji tuntas (Due Diligence Meeting) yang dilakukan bersama-sama dengan profesi dan lembaga penunjang pasar modal lainnya; (d) Kunjungan ke lokasi (Site Visit) apabila diperlukan berdasarkan pertimbangan profesionalnya sehubungan dengan obyek transaksi; (e) Konfirmasi (Cross Checking) dengan profesi atau lembaga penunjang pasar modal lainnya wajib dilakukan KHPM atas hasil uji tuntasnya dengan hasil pemeriksaan yang dilakukan profesi atau lembaga penunjang pasar modal lainnya; (f) Permintaan informasi, konfirmasi, dan keterangan resmi dari instansi pemerintah yang terkait apabila diperlukan atas pertimbangan profesionalnya terkait dengan perusahaan atau obyek transaksi untuk memastikan kebenaran material.

Dalam rangka memperoleh informasi atau Fakta Material, KHPM dapat diwajibkan untuk menambah materi uji tuntas yang tidak terdapat dalam standar profesinya berdasarkan pertimbangan profesionalnya terhadap penambahan materi uji tuntas tersebut sepatutnya atau seharusnya dilakukan (Nasution, 2011). Adapun hal yang perlu mendapat penelitian dan pernyataan dari KHPM adalah mengenai : (a) Akta pendirian atau anggaran dasar Emiten beserta perubahanperubahannya, dalam hal ini penelitian lebih ditekankan atas keaslian, keabsahan, dan kebenaran dokumen atau akta tersebut; (b) Izin usaha Emiten menurut ketentuan yang berlaku (setiap Emiten harus mempunyai izin usaha dan beroperasi sesuai dengan izin usahanya); (c) Bukti kepemilikan atau penguasaan harta kekayaan Emiten, terutama aktiva tetap perlu diketahui status kepemilikannya, seperti bukti semua kepemilikan harta Emiten atau ada yang disewa atau atas nama pihak lain; (d) Perikatan Emiten dengan pihak ketiga, seperti kerja sama, pinjam meminjam, dan lain-lain untuk memastikan pembuatannya sah atau mengikat secara hukum; (e) Penyetoran modal oleh pemegang saham sebelum IPOharus diteliti kebenarannya atas setoran modal seperti yang telah ditentukan dalam anggaran dasar; (f) Perkara baik perdata maupun pidana menyangkut Emiten atau pengurusnya (untuk kepentingan IPO, informasi masalah perkara penting untuk diungkapkan oleh KHPM karena informasi ini sangat penting bagi calon investor sebagai salah satu unsur dalam mempertimbangkan untuk mengambil keputusan); (g) Susunan Direksi dan Dewan Komisaris yang sedang menjabat, KHPM wajib memperoleh surat pernyataan dari masing-masing anggota Direksi dan Dewan Komisaris Perusahaan mengenai apakah masing-masing dari mereka terlibat atau tidak dalam perkara pidana, perdata, kepailitan, pajak, perburuhan, arbitrase dan perkara lainnya); (h) Keadaan ketenagakerjaan perusahaan, seperti bukti pendaftaran tenaga kerja perusahaan, peraturan perusahaan, penggunaan tenaga asing, BPJS, pemenuhan UMR dan lain-lain; (i) Keadaan asuransi yang dimiliki perusahaan, seperti jenis asuransi,obyek yang diasuransikan, dan lain-lain (KHPM wajib memperoleh pernyataan dari direksi mengenai apakah seluruh aset material Perusahaan telah diasuransikan dan apakah jumlah pertanggungannya memadai untuk mengganti objek yang diasuransikan); (j) 
Laporan Keuangan dan management letter sebagai sumber informasi tambahan bagi KHPM mempelajari laporan keuangan Perusahaan yang telah diaudit beserta management letter yang telah dikeluarkan oleh auditor terkait untuk 5 (lima) tahun (Sitompul, 1999).

Dalam hal Emiten melakukan kesalahan karena dokumen atau laporan yuridis yang disampaikan tidak tepat, tidak benar, dan tidak lengkap, maka KHPM dapat turut dimintai pertanggungjawabannya bersamasama Emiten (Nasution, 2011). Apabila pernyataan pendaftaran dalam rangka penawaran umum tidak memuat informasi tentang Fakta Material, maka setiap pihak yang menandatangani pernyataan pendaftaran, baik Emiten maupun Profesi Penunjang Pasar Modal wajib bertanggung jawab, baik secara sendiri-sendiri maupun bersama-sama, atas kerugian yang timbul akibat perbuatan dimaksud. Profesi penunjang pasar modal dapat diberikan sanksi administratif dari badan berwenang yang memberikan izin, persetujuan atau pendaftaran terhadapnya. Sebagaimana kita ketahui sebelumnya bahwa KHPM harus terdaftar di OJK, maka OJK berwenang untuk memberikan sanksi administratif tersebut berupa: (i) peringatan tertulis; (ii) denda yaitu kewajiban untuk membayar sejumlah uang tertentu; (iii) pembatasan kegiatan usaha; (iv) pembekuan kegiatan usaha; (v) pencabutan izin usaha; (vi) pembatalan persetujuan; dan/atau (vii) pembatalan pendaftaran. Pada umumnya sanksi hukum yang diterapkan pada pelanggaran Prinsip Keterbukaan di pasar modal Indonesia adalah sanksi administratif (Putralie \& Zul, 2011).

KHPM dapat pula dikenai sanksi pidana berdasarkan ketentuan dalam UU No. 8 Tahun 1995 apabila terbukti membuat pernyataan tidak benar mengenai Fakta Material dengan ancaman pidana penjara paling lama 10 (sepuluh) tahun dan denda paling banyak Rp. 15.000.000.000,00 (lima belas miliar rupiah). Kemudian, UU No. 8 Tahun 1995 secara implisit juga membuka peluang kepada setiap pihak yang menderita kerugian untuk menuntut ganti rugi secara perdata (perbuatan melawan hukum), khususnya investor. Hal itu sebagai akibat dari tindakan pelanggaran atas UU No. 8 Tahun 1995 dan peraturan pelaksanaannya kepada pihak-pihak yang bertanggung jawab atas pelanggaran tersebut, termasuk KHPM.

KHPM tetap dapat melakukan pembelaan terhadap apa yang telah dia lakukan karena KHPM hanya bertanggung jawab atas pendapat atau keterangan yang diberikan selama ia bertindak secara profesional untuk bertindak secara cermat, seksama dan hati-hati serta jujur dan transparan mengungkapkan kebenaran atas informasi atau fakta material yang diperoleh, diketahui, atau sepatutnya diketahui sehingga informasi yang disajikan tidak menyesatkan.

\section{Pihak yang Berwenang Menentukan Pelanggaran KHPM dalam melakukan Uji Tuntas pada proses IPO}

Uji tuntas (Legal Due Diligence) yang dilakukan oleh KHPM terhadap dokumendokumen yang diberikan oleh Emiten, harus dilakukan secara cermat dan hati-hati, sehingga hasil dari uji tuntas yang dituangkan dalam suatu pendapat hukum (Legal Opinion) benar-benar telah sesuai dengan Prinsip Keterbukaan dalam pasar modal, yaitu memuat seluruh Fakta Material yang dapat mempengaruhi keputusan investor untuk membeli atau tidak membeli saham Emiten di pasar perdana. Terkait dengan permasalahan di atas, terdapat tiga analisa sebagai berikut:

a. Analisa Pertama: OJK sebagai otoritas yang berwenang menyatakan KHPM melakukan kesalahan atau pelanggaran dalam uji tuntas dalam rangka IPO.

Sebelum terbitnya Undang-Undang No. 21 Tahun 2011 tentang Otoritas Jasa Keuangan (UU No. 21 Tahun 2011), terdapat sebuah badan bernama Badan Pengawas Pasar Modal dan Lembaga Keuangan (Bapepam-LK) 
yang dibentuk berdasarkan UU No. 8 Tahun 1995 dan bertugas melakukan pembinaan, pengaturan, serta pengawasan sehari-hari kegiatan Pasar Modal. Adapun sejak berdirinya OJK, tugas dan wewenang pengaturan serta pengawasan kegiatan jasa keuangan di sektor Pasar Modal beralih dari Bapepam ke OJK dan UU No. 8 Tahun 1995 masih tetap berlaku. Terkait tugas dan wewenang tersebut, OJK berwenang antara lain untuk: (1) Menetapkan persyaratan dan tata cara Pernyataan Pendaftaran serta menyatakan, menunda, atau membatalkan efektifnya Pernyataan Pendaftaran; (2) Mengadakan pemeriksaan terhadap setiap Pihak yang diduga melakukan atau terlibat dalam pelanggaran terhadap UU No. 8 Tahun 1995 dan/atau peraturan pelaksanaannya; (3) Mengadakan pemeriksaan dan penyidikan terhadap setiap Pihak dalam hal terjadi peristiwa yang diduga merupakan pelanggaran terhadap Undang-undang ini dan atau peraturan pelaksanaannya;

Mengenakan sanksi administratif atas pelanggaran UU No. 8 Tahun 1995 dan/atau peraturan pelaksanaannya yang dilakukan oleh setiap Pihak yang memperoleh izin, persetujuan, atau pendaftaran dari OJK (dahulu Bapepam-LK). Adapun sanksi administratif yang dapat dijatuhkan oleh OJK berupa : (a) peringatan tertulis; (b) denda yaitu kewajiban untuk membayar sejumlah uang tertentu; (c) pembatasan kegiatan usaha; (d) pembekuan kegiatan usaha; (e) pencabutan izin usaha; (f) pembatalan persetujuan; (g) pembatalan pendaftaran; (5) Menetapkan syarat dan/atau mengizinan pihak yang diduga melakukan atau terlibat dalam pelanggaran terhadap UU No. 8 Tahun 1995 dan/atau peraturan pelaksanaannya untuk melakukan tindakan tertentu yang diperlukan dalam rangka penyelesaian kerugian yang timbul.
UU No. 8 Tahun 1995 mengatur pihak-pihak yang dapat dijatuhi sanksi administratif, salah satunya KHPM. Dalam Peraturan Pemerintah No. 46 tahun 1995 tentang Tata Cara Pemeriksaan di Pasar Modal (PP No. 46 Tahun 1995) diatur antara lain : (1) Tujuan pemeriksaan adalah membuktikan ada atau tidak adanya pelanggaran atas peraturan perundangundangan di bidang pasar modal; (2) Pemeriksaan tersebut dapat dilakukan dalam hal: (a) Adanya laporan, pemberitahuan atau pengaduan tentang adanya pelanggaran atas peraturan perundang-undangan di bidang pasar modal; (b) Tidak dipenuhinya kewajiban yang harus dilakukan oleh KHPM yang memperoleh perizinan, persetujuan atau pendaftaran dari OJK.

Sehubungan dengan kewenangan OJK yang dapat mengadakan pemeriksaan terhadap KHPM yang diduga melanggar UU No. 8 Tahun 1995 dan/atau peraturan pelaksanaanya, maka OJK diberi wewenang untuk: (1) Meminta keterangan dan atau konfirmasi dari KHPM yang diduga melakukan atau terlibat dalam pelanggaran; (2) Mewajibkan KHPM yang diduga melakukan atau terlibat dalam pelanggaran untuk melakukan atau tidak melakukan kegiatan tertentu; (3) Memeriksa dan atau membuat salinan terhadap catatan, pembukuan, dan atau dokumen lain, baik milik KHPM yang diduga melakukan atau terlibat dalam pelanggaran maupun milik pihak lain apabila dianggap perlu; dan/atau (4) Menetapkan syarat dan atau mengizinkan KHPM yang diduga melakukan pelanggaran untuk melakukan tindakan tertentu yang diperlukan dalam rangka penyelesaian kerugian yang timbul. Adapun penyelesaian dimaksud antara lain berupa penyelesaian secara perdata.

Semua kewenangan tersebut termasuk ke dalam fungsi pemeriksa yang dimiliki oleh OJK berdasarkan UU 
No. 8 Tahun 1995 jo. UU No. 21 Tahun 2011 (Rokmatussa'dyah \& Suratman, 2010). Berdasarkan uraian di atas terdapat poin-poin penting sehubungan dengan kewenangan pemeriksaan OJK di bidang pasar modal dikaitkan dengan ada atau tidaknya kesalahan atau pelanggaran KHPM dalam uji tuntas dalam rangka IPO, yaitu: (1) Dalam menjalankan fungsi pemeriksa, UU No. 8 Tahun 1995 telah memberi memberikan kewenangan Extra Judicial kepada OJK untuk memeriksa kesalahan atau pelanggaran dalam uji tuntas dalam rangka IPO. Dalam sistem hukum di Indonesia, selain pengadilan negara yang berada dalam lingkungan kekuasaan kehakiman yang digariskan amandemen oleh Pasal 24 ayat (2) UUD 1945 dan Pasal 2 jo. Pasal 10 ayat (2) Undang-Undang No. 4 Tahun 2004, terdapat juga sistem penyelesaian sengketa berdasarkan yurisdiksi khusus (Specific Jurisdiction) yang diatur dalam berbagai peraturan perundangundangan. Sistem dan badan yang bertindak melaukan penyelesaian itu disebut peradilan semu atau Extra Judicial, dimana kedudukan dan organisasinya berada di luar kekuasaan kehakiman (Harahap, 2008); (2) Dalam hal terbukti adanya pelanggaran KHPM dalam uji tuntas dalam rangka IPO, maka OJK dapat menjatuhkan sanksi administratif terhadap KHPM tersebut, salah satunya sampai dengan tahap pencabutan Surat Tanda Terdaftar ("STTD”) sebagai KHPM; (3) OJK dapat menetapkan syarat dan/atau mengizinkan KHPM yang melakukan pelanggaran dan/atau kesalahan untuk mengambil tindakan tertentu dalam rangka penyelesaian kerugian secara perdata.

b. Analisa Kedua: Pengadilan Negeri juga berwenang menyatakan KHPM melakukan kesalahan atau pelanggaran dalam uji tuntas dalam rangka IPO.
Dalam Undang-Undang No. 48 Tahun 2009 tentang Kekuasaan Kehakiman diatur tentang lingkungan peradilan yang terdiri dari: Peradilan Umum (Pengadilan Negeri), Pengadilan Agama, Pengadilan Militer, Pengadilan Tata Usaha Negara dan Mahkamah Konstitusi. Dalam UU No. 8 Tahun 1995 diatur bahwa jika Pernyataan Pendaftaran dalam rangka Penawaran Umum memuat informasi yang tidak benar tentang Fakta Material atau tidak memuat informasi tentang Fakta Material sesuai dengan ketentuan Undang-undang ini dan/atau peraturan pelaksanaannya sehingga informasi dimaksud menyesatkan, maka : (1) Setiap Pihak yang menandatangani Pernyataan Pendaftaran; (2) Direktur dan komisaris Emiten pada waktu Pernyataan Pendaftaran menjadi efektif; (3) Penjamin Pelaksana Emisi Efek; dan (4) Profesi Penunjang Pasar Modal (salah satunya KHPM) atau Pihak lain yang memberikan pendapat atau keterangan dan atas persetujuannya dimuat dalam Pernyataan Pendaftaran, wajib bertanggung jawab, baik sendirisendiri maupun bersama-sama, atas kerugian yang timbul akibat perbuatan dimaksud. Di dalam UU No. 8 Tahun 1995 sama sekali tidak mengatur larangan bagi pihak yang merasa dirugikan oleh KHPM untuk langsung mengajukan tuntutan keperdataannya ke Pengadilan Negeri. Dengan dibukanya kesempatan menuntut ganti rugi (secara perdata) oleh UU No. 8 Tahun 1995, maka sebenarnya banyak segi dari pelanggarakan hukum pasar modal dapat dimintakan tanggungjawab perdata secara bayaran ganti rugi, terutama dengan adanya pasal "Cath All" yakni Pasal 111 UU No. 8 Tahun 1995 (Fuady, 1996). Namun demikian, Pasal 111 UU No. 8 Tahun 1995 bukanlah "benteng terakhir" dari tuntutan perdata atas pelanggaran di bidang pasar modal, sebab jika karena apapun Pasal 111 UU No. 8 Tahun 1995 
tidak dapat diterapkan, masih ada "the last resort" yang lain untuk dapat menjaring si pelanggar hukum pasar modal untuk dapat dimintakan tanggung jawab perdatanya, yaitu lewat perbuatan melawan hukum sebagaimana Pasal 1365 KUHPerdata. Pengaturan di dalam Pasal 111 UUPM tersebut merupakan pengaturan yang sejalan dengan apa yang dikenal dengan perbuatan melanggar melawan hukum yang diatur di dalam Pasal 1365 KUHPerdata (Rahmawati \& Abubakar, 2019).

Untuk menentukan kesalahan dan/atau pelanggaran dalam uji tuntas oleh KHPM dalam rangka IPO dapatlah diajukan juga melalui Pengadilan Negeri dengan alasan-alasan sebagai berikut : (1) Pasal 111 UU No. 8 Tahun 1995 telah memberikan landasan hukum bagi setiap Pihak yang menderita kerugian sebagai akibat dari pelanggaran atas UU No. 8 Tahun 1995 dan/atau peraturan pelaksanaannya dapat menuntut ganti rugi, baik sendirisendiri maupun bersama-sama dengan Pihak lain yang memiliki tuntutan yang serupa, terhadap Pihak atau Pihak-Pihak yang bertanggung jawab atas pelanggaran tersebut; (2) Gugatan perbuatan melawan hukum dan ganti rugi sebagaimana Pasal 1365 KUHPerdata dalam pembuktiannya salah satunya harus ada unsur kesalahan, sehingga ada atau tidak adanya pelanggaran dan/atau kesalahan KHPM dalam uji tuntas dalam rangka IPO dapat sekaligus diperiksa oleh Pengadilan Negeri; (3) Pengadilan Negeri selaku lembaga yudikatif berwenang untuk memeriksa dan mengadili gugatan perdata (perbuatan melawan hukum dan ganti rugi); (4) OJK hanya berwenang memberi sanksi administratif, sedangkan pemberian hukuman ganti rugi dalam konteks gugatan perdata adalah wewenang Pengadilan Negeri karena Pengadilan Negeri berwenang menjatuhkan Putusan Condemnatoir (bersifat menghukum) dan sita jaminan atas harta kekayaan KHPM, sedangkan wewenang atas Putusan Condemnatoir dan sita jaminan tersebut tidak dimiliki oleh OJK, baik berdasarkan UU No. 8 Tahun 1995 dan/atau peraturan pelaksanaannya maupun UU No. 21 Tahun 2011 sendiri. Hal ini mengingat Pengadilan Negeri termasuk Lembaga Yudikatif, sedangkan OJK termasuk Lembaga Eksekutif yang tidak pernah ada sejarahnya hasil pemeriksaannya diberikan irah-irah Putusan "Demi Keadian Berdasarkan Ketuhanan Yang Maha Esa" seperti layaknya Putusan Pengadilan; (5) UU No. 8 Tahun 1995 sendiri memberikan liabilitas yuridis khusus terhadap pihak tertentu (salah satunya KHPM), yang mana sistem pertanggungjawaban khusus ini berlaku terhadap pelanggaran terhadap informasi yang misleading (Fuadi, 1996)

c. Analisa Ketiga: kewenangan berjenjang dimulai dari pemeriksaan oleh OJK, kemudian dapat dilanjutkan ke Pengadilan.

Dalam hal ada dugaan pelanggaran yang dilakukan KHPM dalam uji tuntas dalam rangka IPO, maka pertamapertama harus ditempuh terlebih mekanisme pemeriksaan di OJK sebagaimana diatur dalam PP No. 46 Tahun 1995. Setelah ditemukan pelanggaran, investor dapat memilih apakah akan mengajukan gugatan Perbuatan Melawan dan Ganti Rugi ke Pengadilan atau menyerahkannya sebagai laporan mengenai dugaan tindak pidana di pasar modal kepada Pejabat Pegawai Negeri Sipil. 


\section{Efektifitas Peraturan Perundang- Undangan di Bidang Pasar Modal dan Standar Profesi HKHPM dalam Mengatur mengenai Pertanggungjawaban KHPM atas Kesalahan yang Dilakukannya}

a. KHPM dalam Peraturan Perundangundangan

KHPM tidak dapat dimintai pertanggungjawaban dalam hal pihak yang bersangkutan telah bertindak secara profesional dan telah mengambil langkah-langkah yang cukup untuk memastikan bahwa: 1) pernyataan yang dimuat dalam pernyataan pendaftaran adalah benar; 2) tidak ada Fakta Material yang diketahuinya yang tidak dimuat dalam pernyataan pendaftaran yang diperlukan agar pernyataan pendaftaran tersebut tidak menyesatkan. Adapun tuntutan ganti rugi maksimal diajukan dalam jangka waktu 5 (lima) tahun sejak pernyataan pendaftaran efektif.

\section{b. KHPM dalam Standar Profesi HKHPM}

Keberadaan pendapat hukum sangat berguna bagi pemodal dalam mempertimbangkan rencana investasinya. Dalam melaksanakan uji tuntas, terdapat 2 (dua) prinsip utama yang harus dipegang oleh KHPM yaitu: (1) Prinsip Keterbukaan, Uji Tuntas dilakukan untuk memenuhi Prinsip Keterbukaan di pasar modal agar kepentingan publik terlindungi. Dalam konteks ini, Konsultan Hukum harus mengungkapkan adanya pelanggaran, kelalaian, ketentuan-ketentuan yang tidak lazim dalam dokumenkorporasi, informasi atau fakta material lainnya yang dapat menimbulkan risiko bagi Perusahaan; (2) Prinsip Materialitas, Uji Tuntas dilakukan dengan memperhatikan prinsip materialitas, yaitu informasi atau fakta material yang relevan mengenai peristiwa, kejadian, atau fakta yang dapat mempengaruhi harga Efek pada Bursa Efek atau keputusan pemodal, calon pemodal atau pihak lain yang berkepentingan atas informasi atau fakta tersebut.

Peran KHPM dalam memberikan dimensi keterbukaan, keadilan, ketertiban serta kepastian hukum menjadi vital bagi penyelenggaraan kegiatan pasar modal mengingat sektor keuangan ini sangat rentan dengan berbagai risiko investasi. Selain itu, sektor pasar modal juga rentan terhadap terjadinya suatu tindakan oleh salah satu pihak yang berakibat pada timbulnya kerugian pada pihak lain (Rahadiyan, 2014). Dalam menjalankan profesinya, KHPM wajib menunjukkan integritasnya, yaitu secara jujur dan transparan mengungkapkan kebenaran atas informasi atau Fakta Material yang diperoleh, diketahui, atau sepatutnya diketahui sehingga informasi yang disajikan tidak menyesatkan.

Dahulu, pada tahun 2005 KHPM diharuskan untuk memperoleh surat keterangan mengenai perkara dari pengadilan, pengadilan niaga, arbitrase, pajak dan sengketa lainnya. Namun, dengan adanya peningkatan secara signifikan kegiatan penawaran umum dan banyaknya perusahaan yang terlibat dalam IPO, ketentuan tersebut dapat menimbulkan beban administrasi yang besar bagi lembaga-lembaga diatas, padahal kapasitas lembaga-lembaga tersebut dalam menangani tugas utamanya masih cukup terbatas. Oleh karenanya, pada tahun 2012, KHPM hanya cukup mendapatkan surat pernyataan dari Direksi saja bahwa perusahaan bebas dari perkara di muka pengadilan, pengadilan niaga, arbitrase, pajak atau sengketa lainnya atau klaim yang mungkin timbul, yang secara material dapat mempengaruhi kelangsungan usaha perusahaan. Sehingga, yang sering terjadi adalah Direksi tidak terus terang kepada KHPM mengenai perkara apa yang pernah, sedang dan/atau mungkin 
muncul dikemudian hari dalam perusahaan. KHPM sebenarnya dapat melakukan pemeriksaan tentang kemungkinan timbulnya gugatan dari pihak lain terhadap perusahaan. Hal ini dapat dilakukan dengan meneliti korespondensi yang ada, yang mengindikasikan adanya kemungkinan gugatan tersebut (Balfas, 2012).

\section{c. Pengaturan Standar Profesi KHPM dikaitkan dengan Praktik}

Pemeriksaan hukum juga dapat menjangkau hal-hal lain seperti sengketa atau kemungkinan sengketa yang akan dihadapi perusahaan, baik di lembaga-lembaga peradilan atau lembaga penyelesaian sengketa dan perselisihan lainnya. Dengan cakupan yang sedemikian luas sebenarnya pemeriksaan hukum tidak jauh berbeda dengan dengan apa yang dilakukan oleh akuntan ketika melakukan pemeriksaan (audit) atas pembukuan dan keuangan perusahaan. Namun demikian, terlepas dari pentingnya peranan pemeriksaan hukum dan pendapat hukum misalnya dalam suatu penawaran umum efek, OJK sendiri sebagai otoritas di pasar modal sama sekali tidak melakukan pengaturan secara khusus atas masalah ini.

Peran KHPM sangat penting dan perlu diatur dengan lebih rinci mengenai sistem penyelesaian sengketa dan tuntutan ganti rugi atas suatu kondisi dimana terjadi kekeliruan oleh KHPM dalam melakukan uji tuntas yang menyebabkan informasi yang sampai ke publik menjadi keliru dan merugikan pemodal. Sejauh ini, peraturan perundang-undangan memungkinkan adanya ganti rugi yang dituntut kepada KHPM atas kekeliruannya yang dapat dibuktikan merugikan Investor. Namun, tidak terdapat kejelasan mengenai prosedur dan langkah yang harus diambil bagi Investor untuk dapat menuntut ganti kerugian dan tindak lanjut atas perdagangan atas saham perusahaan Emiten yang merugikan tersebut. Oleh karena itu, berdasarkan uraian diatas dapat disimpulkan bahwa peraturan hukum yang mengatur mengenai penerapan ganti kerugian bagi KHPM yang melakukan kekeliruan dalam laporan uji tuntas dan pendapat dari segi hukum khususnya pada saat IPO sangat diperlukan. Bahwa agar upaya optimalisasi pengawasan pasar modal khususnya berkaitan dengan penegakan hukum dapat senantiasa dilakukan maka diperlukan suatu pedoman yang jelas mengenai standar pelaksanaan dan target tindak lanjut atas dugaan terjadinya kejahatan atau pelanggaran di bidang pasar modal (Rahadiyan, 2014).

\section{Simpulan dan Saran}

Berdasarkan hasil analisis dalam penelitian hukum ini, maka dapat ditarik simpulan sebagai berikut: (1) Keberadaan KHPM sebagai salah satu profesi penunjang dalam pasar modal sangat diperlukan calon Emiten di setiap proses IPO. Dengan peranannya melakukan pemeriksaan dokumen hukum (Legal Audit) dan memberikan pendapat dari segi hukum (Legal Opinion) mengenai keadaan Emiten melalui proses uji tuntas, KHPM dianggap ikut bertanggungjawab minimal untuk bidang pekerjaan yang dilakukannya untuk Emiten. Namun demikian, KHPM tidak bertanggungjawab atas kerugian yang diderita oleh Investor apabila KHPM telah melakukan penilaian atau memberikan pendapatnya secara profesional berdasarkan Prinsip Keterbukaan (Disclosure) di bidang pasar modal; (2) Terdapat 2 (dua) otoritas yang memiliki kewenangan menentukan adanya pelanggaran atau kesalahan uji tuntas yang dilakukan oleh KHPM pada proses IPO, yaitu pertamaa, OJK sebagai otoritas pengawas dalam konteks penerapan hukum administratif di bidang pasar modal dan Pengadilan Negeri sebagai perangkat peradilan tingkat pertama dalam konteks hukum perdata yang memproses Gugatan Perbuatan Melawan Hukum dan Ganti Rugi 
terkait transaksi atau kegiatan dalam pasar modal; (3) Pada dasarnya UU No. 8 Tahun 1995 mengatur mengenai adanya kemungkinan menuntut ganti rugi kepada KHPM atas kekeliruan yang dibuat dalam pendapat hukumnya. Namun demikian, UU No. 8 Tahun 1995 tidak mengatur secara rinci dan spesifik mengenai mekanisme perhitungan ganti rugi. Sejauh ini belum terdapat ketentuan yang spesifik mengenai pembuktian adanya kerugian yang berkaitan langsung dengan adanya kekeliruan Pendapat Hukum dari KHPM.

Berdasarkan hasil penelitian dan pembahasan diatas, maka dalam kesempatan kali ini patut disampaikan saran, yaitu: (1) OJK perlu membuat suatu peraturan yang mengatur bahwa untuk menentukan ada atau tidaknya pelanggaran di bidang pasar modal oleh KHPM karena tidak mengungkap Fakta Material dapat langsung diajukan ke Pengadilan Negeri, dengan syarat mengikutsertakan pihak OJK, baik sebagai Tergugat mupun Turut Tergugat. Hal ini semata-mata agar Investor yang mencari keadilan dapat mempunyai tahapan yang lebih singkat daripada harus melalui OJK dahulu baru kemudian diajukan Gugatan ke Pengadilan Negeri. Selain itu, Putusan Pengadilan Negeri mempunyai kekuatan eksekusi yang lebih pasti; (2) OJK perlu mengatur besarnya ganti rugi yang harus dibayarkan KHPM kepada Investor dalam hal KHPM terbukti tidak mengungkap Fakta Material dalam Prospektus. Hal ini agar terdapat kepastian hukum terkait nilai ganti rugi, baik bagi KHPM maupun Investor itu sendiri, jangan sampai ada ganti rugi yang terlalu kecil dan/atau terlalu besar yang merugikan kedua pihak.

\section{DAFTAR PUSTAKA}

Balfas, M. H. (1994). Kejahatan di Pasar Modal: Sebuah Perkenalan. Jurnal Hukum Dan Pembangunan, 24(3), 205223.

\section{Balfas, M. H. (2012). Hukum Pasar Modal} Indonesia. Jakarta: Tatanusa.
Fuadi, M. (1996). Pasar Modal Modern. Bandung: Citra Aditya Bakti.

Fuady, M. (1996). Pasar Modal Modern. Bandung: PT Citra Adiyta Bakti.

Haidar, F. (2015). Perlindungan Hukum Bagi Investor Terhadap Praktik Kejahatan Insider Trading Pada Pasar Modal di Indonesia. Jurnal Cita Hukum, 3(1), 134-152.

Harahap, M. Y. (2008). Hukum Acara Perdata. Jakarta: Sinar Grafika.

Marzuki, P. M. (2014). Penelitian Hukum. Jakarta: Prenada Media Group.

Nasarudin, I., \& Surya, I. (2004). Aspek Hukum Pasar Modal Indonesia. Jakarta: Kencana.

Nasarudin, M. I. (2017). Keterbukaan Informasi Oleh Perusahaan Publik. Jurnal Hukum Dan Pembangunan, 18(3), 248-253.

Nasarudin, M. I., \& Surya, I. (2004). Aspek Hukum Pasar Modal Indonesia. Jakarta: Kencana.

Nasution, B. (2011). Keterbukaan Dalam Pasar Modal. Jakarta: FHUI-Program Pasca Sarjana.

Purba, A. Z. U. (1990). Pokok-Pokok Pikiran Mengenai Keterbukaan Melalui Pendapat Hukum. Jurnal Hukum Dan Pembangunan, 20(2), 115-120.

Purba, A. Z. U. (1995). Tanggungjawab Profesi Penunjang Pasar Modal di Indonesia. Jurnal Hukum Dan Pembangunan, 25(2), 114-127.

Putralie, E. M., \& Zul, M. (2011). Mercatoria. Mercatoria, 4(1), 12-22.

Rahadiyan, I. (2014). Hukum Pasar Modal Indonesia. Yogyakarta: UII Press.

Rahmawati, E.; Abubakar, L. (2019). Peranan Penyelesaian Sengketa Pasar Modal: Suatu Tinjauan Atas Perkara Perdata Terkait Transaksi Repo. Jurnal Bina Mulia Hukum, 4(1), 130-149. 
Ratna. (2006). Tinjauan Hukum Terhadap Keterbukaan Informasi Hubungannya Dengan Perlindungan Hukum Bagi Investor. Jurnal Hukum Dan Pembangunan, 36(4), 404-419.

Rohendi, A. (2017). Kewajiban Dan Tanggung Jawab Konsultan Hukum Sebagai Profesi Penunjang Pasar Modal. Jurnal Ecodemica, 1(1), 59-71.

Rokmatussa'dyah, A., \& Suratman. (2010). Hukum Investasi dan Pasar Modal. Jakarta: Sinar Grafika.

Sitompul, A. (1999). Due Diligence dan Tanggungjawab Lembaga-lembaga Penunjang Pada Proses Penawaran Umum. Bandung: Citra Aditya Bhakti.
Soekanto, S. (2015). Pengantar Penelitian Hukum. Jakarta: Universitas Indonesia.

Soekanto, S., \& Mamudji, S. (2004). Penelitian Hukum Normatif. Jakarta: Raja Grafindo Persada.

Sujatmiko, B.; Suryanti, N. (2017). Perlindungan Hukum Bagi Investor Pada Perusahaan Terbuka Yang Pailit Ditinjau Dari Hukum Kepailitan. Jurnal Bina Mulia Hukum, 2(1), 15-25.

Sutedi, A. (2009). Segi-Segi Hukum Pasar Modal. Jakarta: Ghalia Indonesia.

Wiradipradja, E. S. (2016). Penuntun Praktis Metode Penelitian dan Penulisan Karya Ilmiah. Bandung: Keni Media. 